\title{
Why internet-based education?
}

\section{Morton Ann Gernsbacher*}

Department of Psychology, University of Wisconsin-Madison, Madison, WI, USA

\author{
Edited by: \\ Stanley N. Bursten, Santa Barbara \\ City College, USA \\ Reviewed by: \\ Thomas James Lundy, Independent \\ Researcher, USA \\ Robin Paul Clark, Aston University, UK \\ *Correspondence: \\ Morton Ann Gernsbacher, \\ Department of Psychology, University \\ of Wisconsin-Madison, Madison, \\ WI 53706, USA \\ e-mail:magernsb@wisc.edu
}

This essay illustrates five ways that Internet-based higher education can capitalize on fundamental principles of learning. Internet-based education can enable better mastery through distributed (shorter, more frequent) practice rather than massed (longer, less frequent) practice; it can optimize performance because it allows students to learn at their peak time of their day; it can deepen memory because it requires cheat-proof assignments and tests; it can promote critical thinking because it necessitates intellectual winnowing and sifting; and it can enhance writing skills by requiring students to write frequently and for a broad audience.

Keywords: Internet-based learning, online learning, higher education, asynchronous learning, depth of processing, optimal time of day, writing skills

\section{WHY INTERNET-BASED COURSES?}

Over 7 million post-secondary students in the United States - a third of all U.S. college and university students - were enrolled in an Internet-based course last year. Enrollment in Internetbased courses increased a whopping $440 \%$ during the past decade (Allen and Seaman, 2014). For the coming decade, most college and university presidents predict that all their students will take an Internet-based course (Parker etal., 2011). Internetbased higher education has moved "from a fad to a fixture" (Selingo, 2013, p. 97).

A decade ago, I volitionally moved all my University of Wisconsin-Madison courses onto the Internet. I wanted to harness the power of the Internet. I also wanted to harness fundamental principles of learning. In this essay, I will illustrate five reasons why Internet-based higher education can capitalize on principles of learning and, therefore, why Internet-based education can be effective pedagogy.

\section{INTERNET-BASED HIGHER EDUCATION CAN LEAD TO BETTER MASTERY}

A core principle of learning is that shorter, more-frequent episodes of practice lead to better mastery than longer, less-frequent episodes (Ruch, 1928; Oseas and Underwood, 1952; Underwood, 1961). Acquiring skills through more frequent practice is considered distributed learning, whereas acquiring skills through less frequent practice is considered massed learning. Distributed learning almost always trumps massed learning (Benjamin and Tullis, 2010).

Distributed learning's advantage over massed learning has been demonstrated for students of all ages (e.g., Seabrook et al., 2005), acquiring mastery in a wide range of courses (e.g., college composition, Kellogg and Raulerson, 2007; college biology, Reynolds and Glaser, 1964; and college statistics, Budé et al., 2010). Harness the pedagogical power of distributed learning has been one of the most common battle cries for improving higher education (e.g., Willingham, 2002; Roediger and Pyc, 2012).

Internet-based higher education enables more frequent engagement with the material than traditional face-to-face higher education (Holzinger et al., 2009). For example, at my university most face-to-face undergraduate classes meet only twice a week. Many seminar-style courses, including graduate-level courses, meet only once a week. While we professors would like to believe that our students continue to practice their skills when they are not in class, many students wait until the night before class meets to engage with the material. The students then attend class, but several days if not a week pass before the students engage with the material again.

In contrast, Internet-based courses can and should be constructed to require students to engage with the material every day (Newlin and Wang, 2002; Elvers et al., 2003). For example, in my Internet-based courses, students are required to log in almost daily and to complete multiple, small assignments each week (e.g., Foertsch and Gernsbacher, 2008; Gernsbacher, 2013). Furthermore, the assignments are constructed so that it is not in the students' best interest to mass their practice and attempt to do a week's worth of assignments in one sitting. Doing so would be akin to trying to do a week's worth of athletic workouts in one trip to the gym; trying to eat a week's worth of food in one sitting; trying to visit five European cities in 1 day. It simply would not be feasible.

Thus, Internet-based higher education enables students to distribute their learning over time, to engage with the material in short, frequent episodes, and to master the material in increments, rather than in once- or twice-a-week doses. These short, frequent, and distributed episodes of practice can lead to better mastery.

\section{INTERNET-BASED HIGHER EDUCATION CAN OPTIMIZE PERFORMANCE}

Psychological science, as well as personal observation, identifies differences among us in our optimal time of the day. Our cognitive processes peak at our optimal times and flounder at our non-optimal times (May and Hasher, 1998; May, 1999). Empirical research documents that every cognitive process - memory (West et al., 2002), attention (May, 1999), language comprehension (Natale and Lorenzetti, 1997), even intelligence testing 
(Goldstein et al., 2007), and attitude change (Martin and Marrington, 2005) - operates at a peak during our optimal time of the day.

The older we get, the earlier in the day we find our peak time for performance (May etal., 1993), which might explain why, at least at my university, many professors like to teach at 8:00 AM. However, at 8:00 AM most traditional-age undergraduate students have barely gone through two full stages of REM sleep (Randall, 2012). Even if students have tried to get a good night of sleep, their biology dictates against morning hours bringing their optimal performance (American Academy of Pediatrics, 2014). Indeed, by puberty, students' optimal time of the day has already shifted beyond the traditional school day to evening (Kim et al., 2002).

The beauty of Internet-based higher education is that learners can engage with the material - and the course - at whatever time of the day or night works best for them. For example, in my Internet-based courses, all assignments are due at 11:59 PM, but students can complete the assignments hours or days before they are due. Students can also engage with the material around the clock (i.e., 24/7). Thus, Internet-based higher education can optimize performance by allowing students to capitalize on their own optimal time of the day.

\section{INTERNET-BASED HIGHER EDUCATION CAN DEEPEN MEMORY}

Psychological science documents the value of deeper levels of processing (Craik, 2010). Information that is processed to a deeper level is remembered better; more deeply processed information is also more tightly connected to previously learned and subsequently learned concepts. Internet-based learning can deepen levels of processing for one simple reason: To allay concerns about cheating, assignments and exams must assess deeper levels of processing.

One of the primary concerns that faculty have about Internetbased teaching is the worry that students will cheat (Parker et al., 2011). By cheat, instructors usually mean look up the answers. But if the answer to a question, or the solution to a problem, is just a click away - be the assignment Internet-based or in-person that assignment is not assessing a very deep level of processing. We should probably not assess such superficial knowledge in our higher education courses.

Therefore, in my Internet-based courses, I expect students to take advantage of all the material the world wide web has to offer. I encourage students to click and scroll and open as many browser windows as they want when they are completing assignments, solving problems, and taking exams. If the answer to one of my test questions is just one click away, it is not a very good test question.

Similarly, if instructors hesitant-to-embrace Internet-based instruction are worried about their students enlisting a ringer to complete their assignments or take their tests, my response is the same: do not design assessments that anyone can simply parachute into - regardless of whether you are designing assessments that are Internet-based or in person. Valid assessments should assay mastery of the course material, for which active members of the course should be advantaged.

\section{INTERNET-BASED HIGHER EDUCATION CAN PROMOTE CRITICAL THINKING}

A few years ago, a group of psychology students at the University of Cincinnati refused to spend \$168 to purchase the textbook for their course. Instead they gathered all the information they needed for their course using only the Internet. How did these students fare? Top of the class (Massis, 2013).

How could that be? Isn't the Internet is full of cat videos? Yes, it is (Clark, 2012). But the Internet is also full of 100s of videos that explain how to compute a $t$-test, which is a basic statistical tool for students and scholars. The videos available on YouTube and other Internet-based video sharing sites provide a vibrant component of many curricula, including health education (Akagia, 2008; Burke and Snyder, 2008), African American studies (White, 2009), anatomy (Jaffar, 2012), Shakespeare (Desmet, 2009), music instruction (Kruse and Veblen, 2012), American history (Rees, 2008), and nursing (Clifton and Mann, 2011).

Moreover, as research published in Nature demonstrated, information available on the Internet-based Wikipedia is just as accurate as information available in the print-based Encyclopedia Britannica (Giles, 2005). That is not to say that either Wikipedia or Encyclopedia Britannica is $100 \%$ accurate, but Wikipedia is no less accurate than a traditional print-based encyclopedia.

The accuracy of information on the Internet, although commonly underestimated, is one factor that led to the University of Cincinnati students' success with substituting Internet-based information for a standard textbook. The other factor was that the process of gathering information from the Internet evokes more critical thinking than simply reading a textbook. Active learning winnowing and sifting intellectual wheat from chaff - facilitates learning (Tsui, 1999; Prince, 2004; Chi, 2009; Freeman et al., 2014). The Internet magnifies the opportunities for winnowing and sifting (Newlin and Wang, 2002; Weiler, 2004).

\section{INTERNET-BASED HIGHER EDUCATION CAN ENHANCE WRITING SKILLS}

After critical thinking skills, writing skills are what employees consistently rank as necessary in college graduates [Association of American Colleges and Universities and Hart Research Associates (AAC\&U), 2013; Sternberg, 2013]. However, many collegelevel instructors rate their students' writing skills as only fair (Purcell et al., 2013). Internet-based higher education can enhance students' writing skills by capitalizing on the Internet's inherently text-based mode of communication (Gernsbacher, 2014) and the Internet's inherently broad-based audience (Ellison and Wu, 2008).

For example, across one term of my Internet-based courses, each student composes approximately 85 posts, with each post comprising two to three paragraphs. In essence, each student writes the equivalent of a five-page double-spaced paper each of 15 weeks. Text-based communication on the Internet is a feature, not a bug (Gernsbacher, 2014).

Who reads the equivalent of 50 students' five-page papers each week? I read a sample of them, but the primary readers are the other students in the class. Across the semester, each student reads and comments on over 700 posts written by their peers. Requiring this quantity of reading and writing in a face-to-face college course 
would consume all the class meeting time. That is not a concern with Internet-based courses.

Moreover, as the Stanford Study of Writing attests (ssw.stanford.edu), today's Internet-native students are vastly more experienced writing for the public than we professors were at their age (Fishman et al., 2005). Many of today's college students have written blogs since they were 12 years old and posted Facebook statuses since they were 14; they might have commented on more Internet sites than most professors have read (Keller, 2009).

Therefore, today's students are "almost always less enthusiastic about their in-class writing because it ha(s) no audience but the professor" and it fails to "serve any purpose other than to get them a grade" (Thompson, 2009). Writing to an audience that comprises only the professor is not a concern with Internet-based courses. Posting on a discussion board is de rigueur in most all Internetbased courses, and attaching a document to a common discussion board for all class members to read is just as easy as emailing it to the professor.

Writing to a broad audience (an entire class or an entire Internet) rather than only the professor empirically improves technical aspects of composition (Day et al., 1998); encourages students to write longer and more often (Kaplan et al., 2007); and increases students' mastery of logical, ethical, and emotional appeal, as well as increasing their treatment of opposing views (Gaddis et al., 2000).

The Stanford Study of Writing also points to the fact that textspeak rarely if ever enters into students' course-based writing, an observation I, too, have made. In fact, writing for the Internet increases, rather than decreases, students' grammatical and syntactic skills (Gaddis et al., 2000).

\section{IN SUM}

This essay illustrates five reasons why Internet-based higher education can capitalize on principles of learning and, therefore, why Internet-based education can lead to effective pedagogy. Internetbased education can lead to better mastery by providing short, frequent episodes of practice rather than less frequent bouts of practice. Internet-based education can optimize performance by allowing students to engage with the material - and the course at whatever time of the day works best for them.

Internet-based education can deepen memory by necessitating cheat-proof assignments and exams that engage deeper levels of processing. Internet-based education can promote critical thinking by empowering students to gather multiple sources of information and distinguish wheat from chaff. Lastly, Internet-based education can enhance writing skills by multiplying the writing opportunities with a built-in audience beyond the professor.

A recent meta-analysis by the U. S. Department of Education (2010) evaluated 50 high quality contrasts of Internet-based versus face-to-face courses. The results showed a consistent advantage in student learning from Internet-based higher education courses. However, the report cautioned that the "positive effects (of Internet-based learning) should not be attributed to the media, perse" (p. ix). Indeed, it is likely that any medium will lead to more successful pedagogy if it capitalizes on fundamental principles of learning.

\section{REFERENCES}

Akagia, C. (2008). YouTube? For health education? Am. J. Health Educ. 39, 58-60. doi: 10.1080/19325037.2008.10599015

Allen, I. E., and Seaman, J. (2014). Grade Change: Tracking Online Education in the United States. Wellesley, MA: Babson Survey Research Group and Quahog Research Group.

American Academy of Pediatrics. (2014). School start times for adolescents. Pediatrics 134, 642-649. doi: 10.1542/peds.2014-1697

Association of American Colleges and Universities and Hart Research Associates (AAC\&U). (2013). It Takes More than a Major: Employer Priorities for College Learning and Student Success. Washington, DC: Association of American Colleges and Universities.

Benjamin, A. S., and Tullis, J. (2010). What makes distributed practice effective? Cogn. Psychol. 61, 228-247. doi: 10.1016/j.cogpsych.2010.05.004

Budé, L., Imbos, T., van de Wiel, M. W., and Berger, M. P. (2010). The effect of distributed practice on students' conceptual understanding of statistics. Int. J. Higher Educ. Res. 62, 69-79. doi: 10.1007/s10734-010-9366-y

Burke, S. C., and Snyder, S. L. (2008). YouTube: an innovative learning resource for college health education courses. Int. Electronic J. Health Educ. 11, 39-46.

Chi, M. T. H. (2009). Active-constructive-interactive: a conceptual framework for differentiating learning activities. Top. Cogn. Sci. 1, 73-105. doi: 10.1111/j.17568765.2008.01005.x

Clark, L. (2012). Google's Artificial Brain Learns to Find Cat Videos, Wired Magazine. Available at: http://www.wired.com/2012/06/google-x-neural-network

Clifton, A., and Mann, C. (2011). Can YouTube enhance student nurse learning? Nurse Educ. Today 31, 311-313. doi: 10.1016/j.nedt.2010.10.004

Craik, F. I. M. (2010). "Levels of processing in human memory," in Psychology and the Real World: Essays Illustrating Fundamental Contributions to Society, eds M. A. Gernsbacher, R. W. Pew, L. M., Hough, and J. R. Pomerantz (New York: Worth Publishers), 76-82.

Day, T. M., Raven, M. R., and Newman, M. E. (1998). The effects of world wide web instruction and traditional instruction and learning styles on achievement and changes in student attitudes in a technical writing in an agricommunication course. J. Agric. Educ. 39, 65-75. doi: 10.5032/jae.1998.04065

Desmet, C. (2009). Teaching Shakespeare with YouTube. English J. 99, 65-70.

Ellison, N. B., and Wu, Y. (2008). Blogging in the classroom: a preliminary exploration of student attitudes and impact on comprehension. J. Educ. Multimed. Hypermed. 17, 99-122.

Elvers, C., Polzella, D. J., and Graetz, K. (2003). Procrastination in online courses: performance and attitudinal differences. Teach. Psychol. 30, 159-162. doi: 10.1207/S15328023TOP3002_13

Fishman, J., Lunsford, L., McGregor, B., and Otuteye, M. (2005). Performing writing, performing literacy. Coll. Compos. Commun. 57, 224-252.

Foertsch, J., and Gernsbacher, M. A. (2008). When the medium illuminates the content: exploiting the unique features of online communication in an undergraduate psychology course. Innovate 4:3.

Freeman, S., Eddy, S. L., McDonough, M., Smith, M. K., Okoroafor, N., Jordt, H., et al. (2014). Active learning increases student performance in science, engineering, and mathematics. Proc. Natl. Acad. Sci. U.S.A. 111, 8410-8415. doi: 10.1073/pnas.1319030111

Gaddis, B., Napierkowski, H., Guzman, N., and Muth, R. (2000). A Comparison of Collaborative Learning and Audience Awareness in Two Computer-Mediated Writing Environments. Available at: http://eric.ed.gov/?id = ED455771

Gernsbacher, M. A. (2013). Improving Scholarly Communication: an Online Course, University of Wisconsin-Madison. Available at: http://www.gernsbacherlab.org/ research/online-communication-research/online-courses

Gernsbacher, M. A. (2014). Internet-based communication. Discourse Process. 51, 359-373. doi: 10.1080/0163853X.2014.916174

Giles, J. (2005). Internet encyclopaedias go head to head. Nature 438, 900-901. doi: $10.1038 / 438900$ a

Goldstein, D., Hahn, C. S., Hasher, L., Wiprzycka, U. J., and Zelazo, P. D. (2007). Time of day, intellectual performance, and behavioral problems in morning versus evening type adolescents: is there a synchrony effect? Personal. Individ. Dif. 42, 431-440. doi: 10.1016/j.paid.2006.07.008

Holzinger, A., Kickmeier-Rust, M. D., and Ebner, M. (2009). "Interactive technology for enhancing distributed learning: a study on weblogs," in proceeding of 23rd British HCI Group Annual Conference on People and Computers: Celebrating People and Technology (Swinton: British Computer Society), 23, 309-312. 
Jaffar, A. A. (2012). YouTube: an emerging tool in anatomy education. Anat. Sci. Educ. 5, 158-164. doi: 10.1002/ase.1268

Kaplan, D. S., Rupley, W. H., Sparks, J., and Holcomb, A. (2007). Comparing traditional journal writing with journal writing shared over e-mail list serves as tools for facilitating reflective thinking: a study of preservice teachers. J. Lit. Res. 39, 357-387. doi: 10.1080/10862960701613136

Keller, J. (2009). Studies Explore Whether the Internet Makes Students Better Writers. The Chronicle of Higher Education. Available at: http://chronicle.com/article/Studies-Explore-Whether-the/44476

Kellogg, R. T., and Raulerson, B. A. III. (2007). Improving the writing skills of college students. Psychon. Bull. Rev. 14, 237-242. doi: 10.3758/BF03194058

Kim, S., Dueker, G. L., Hasher, L., and Goldstein, D. (2002). Children's time of day preference: age, gender and ethnic differences. Pers. Individ. Dif. 33, 1083-1090. doi: 10.1016/S0191-8869(01)00214-8

Kruse, N. B., and Veblen, K. K. (2012). Music teaching and learning online: considering YouTube instructional videos. J. Music Technol. Educ. 5, 77-87 doi: 10.1386/jmte.5.1.77_1

Martin, P. Y., and Marrington, S. (2005). Morningness-eveningness orientation, optimal time-of-day and attitude change: evidence for the systematic processing of a persuasive communication. Pers. Individ. Dif. 39, 367-377. doi: 10.1016/j.paid.2005.01.021

Massis, B. E. (2013). Textbook affordability: the library's role. New Library World 114, 179-183. doi: 10.1108/03074801311304087

May, C. P. (1999). Synchrony effects in cognition: the costs and a benefit. Psychon Bull. Rev. 6, 142-147. doi: 10.3758/BF03210822

May, C. P., and Hasher, L. (1998). Synchrony effects in inhibitory control over thought and action. J. Exp. Psychol. Hum. Percept. Perform. 24, 363-379. doi: 10.1037/0096-1523.24.2.363

May, C. P., Hasher, L., and Stoltzfus, E. R. (1993). Optimal time of day and the magnitude of age differences in memory. Psychol. Sci. 4, 326-330. doi: 10.1111/j.1467-9280.1993.tb00573.x

Natale, V., and Lorenzetti, R. (1997). Influences of morningness-eveningness and time of day on narrative comprehension. Pers. Individ. Dif. 23, 685-690. doi: 10.1016/S0191-8869(97)00059-7

Newlin, M. H., and Wang, A. Y. (2002). Integrating technology and pedagogy: web instruction and seven principles of undergraduate education. Teach. Psychol. 29, 325-330. doi: 10.1207/S15328023TOP2904_15

Oseas, L., and Underwood, B. J. (1952). Studies of distributed practice: v. Learning and retention of concepts. J. Exp. Psychol. 43, 143-148. doi: 10.1037/h0062903

Parker, K., Lenhart, A., and Moore, K. (2011). The digital revolution and higher education. Pew Internet. Available at: http://www.pewinternet.org/2011/08/28/thedigital-revolution-and-higher-education

Prince, M. (2004). Does active learning work? A review of the research. J. Eng. Educ. 93, 223-231. doi: 10.1002/j.2168-9830.2004.tb00809.x

Purcell, K., Buchanan, J., and Friedrich, L. (2013). The Impact of Digital Tools on Student Writing and How Writing is Taught in Schools. PewResearch Internet Project. Available at: http://www.pewinternet.org/2013/07/16/the-impact-ofdigital-tools-on-student-writing-and-how-writing-is-taught-in-schools

Randall, D. K. (2012). Dreamland: Adventures in the Strange Science of Sleep. New York: W. W. Norton \& Company.

Rees, J. (2008). Teaching History with YouTube (and other PrimarySource Video Sites on the Internet). Perspectives on History. Available at: http://www.historians.org/publications-and-directories/perspectives-on-history/ may-2008/teaching-history-with-youtube
Reynolds, J. H., and Glaser, R. (1964). Effects of repetition and spaced review upon retention of a complex learning task. J. Educ. Psychol. 55, 297-308. doi: $10.1037 / \mathrm{h} 0040734$

Roediger, H. L. III., and Pyc, M. A. (2012). Inexpensive techniques to improve education: applying cognitive psychology to enhance educational practice. J. Appl. Res. Mem. Cogn. 1, 242-248. doi: 10.1016/j.jarmac.2012.0 9.002

Ruch, T. C. (1928). Factors influencing the relative economy of massed and distributed practice in learning. Psychol. Rev. 35, 19-45. doi: 10.1037/h0074423

Seabrook, R., Brown, G. D. A., and Solity, J. E. (2005). Distributed and massed practice: from laboratory to classroom. Appl. Cogn. Psychol. 19, 107-122. doi: 10.1002/acp.1066

Selingo, J. (2013). College Unbound: The Future of Higher Education and What it Means for Students. New York: New Harvest.

Sternberg, R. J. (2013). Giving Employers What they Don't Really Want. The Chronicle of Higher Education. Available at: http://chronicle.com/article/GivingEmployers-What-They/139877

Thompson, C. (2009). Clive Thompson on the New Literacy, Wired Magazine. Available at: http://archive.wired.com/techbiz/people/magazine/17-09/st_thompson

Tsui, L. (1999). Courses and instruction affecting critical thinking. Res. High. Educ. 40, 185-200. doi: 10.1023/A:1018734630124

U. S. Department of Education. (2010). Evaluation of Evidence-Based Practices in Online Learning: A Meta-Analysis and Review of Online Learning Studies. Washington, DC: Office of Planning, Evaluation, and Policy Development.

Underwood, B. J. (1961). Ten years of massed practice on distributed practice Psychol. Rev. 68, 229-247. doi: 10.1037/h0047516

Weiler, A. (2004). Information-seeking behavior in Generation Y students: motivation, critical thinking, and learning theory. J. Acad. Librariansh. 31, 46-53. doi: 10.1016/j.acalib.2004.09.009

West, R., Murphy, K. J., Armilio, M. L., Craik, F. I. M., and Stuss, D. T. (2002). Effects of time of day on age differences in working memory. J. Gerontol. 57B, 3-10. doi: 10.1093/geronb/57.1.P3

White, E. J. (2009). Coffy, YouTube, and Uncle Ben: the use of film and new media in the teaching of African American Studies at the University of Hawai'i. New Media Higher Educ. 42, 47-53.

Willingham, D. T. (2002). Ask the Cognitive Scientist. Allocating student study time: "Massed" versus "Distributed" practice. Am. Educ. 26, 37-39.

Conflict of Interest Statement: The author declares that the research was conducted in the absence of any commercial or financial relationships that could be construed as a potential conflict of interest.

Received: 30 August 2014; accepted: 10 December 2014; published online: 21 January 2015.

Citation: Gernsbacher MA (2015) Why internet-based education? Front. Psychol. 5:1530. doi: $10.3389 /$ fpsyg.2014.01530

This article was submitted to Educational Psychology, a section of the journal Frontiers in Psychology.

Copyright (C) 2015 Gernsbacher. This is an open-access article distributed under the terms of the Creative Commons Attribution License (CC BY). The use, distribution or reproduction in other forums is permitted, provided the original author(s) or licensor are credited and that the original publication in this journal is cited, in accordance with accepted academic practice. No use, distribution or reproduction is permitted which does not comply with these terms. 